\title{
Early Cambrian eodiscoid trilobite Hupeidiscus orientalis from South China: ontogeny and implications for affinities of Mongolitubulus-like sclerites
}

\author{
GUOXIANG LI, Michael SteINER, MAOYAN ZHU \& XIN ZHAO
}

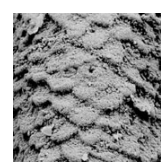

\begin{abstract}
Delicately phosphatized specimens of the eodiscoid Hupeidiscus orientalis were documented from the lower Cambrian Shuijingtuo Formation through acetic acid maceration of limestone samples. The material enables us to better understand the meraspid to holaspid ontogenetic development of $\mathrm{H}$. orientalis, and to evaluate its relations with other eodiscoid taxa occurring in South China. The development of its pygidium and thoracic segments is very similar to that of "Shizhudiscus" longquanensis, suggesting that Shizhudiscus is a junior synonym of Hupeidiscus. However, the synonymization of Hupeidiscus with Tsunyidiscus remains open as little is known about the ontogeny of the latter genus. The spines of $H$. orientalis are of particular importance. Like the enigmatic sclerite taxon Mongolitubulus, its spines are ornamented with a distinctive scaly sculpture, shedding new light on the origin and affinities of Mongolitubulus-like sclerites. The squamose ornament was gradually transformed from granules on the exoskeletal surface at the base of the spines. Other strands of evidence, e.g., the outline, exuviating growth, and the spatio-temporal distribution, also suggest that some isolated sclerites previously assigned to Mongolitubulus are possibly related to the spines of eodiscoid trilobites. This finding implies that such morphologically similar spines may be essentially of multiple pan-arthropod origins (bradoriids, eodiscoids, etc.), and they may be of morphologic analogues rather than homologues, suggesting that Mongolitubulus shall be cautiously used as a generic name unless the circumstance of its type specimens from Mongolia gets clarified. • Key words: eodiscoid, Hupeidiscus, sclerite, Mongolitubulus, Lower Cambrian, South China.
\end{abstract}

LI, G.X., STEINER, M., ZHU, M.Y. \& ZHAO, X. 2012. Early Cambrian eodiscoid trilobite Hupeidiscus orientalis from South China: ontogeny and implications for affinities of Mongolitubulus-like sclerites. Bulletin of Geosciences 87(1), 159-169 (4 figures). Czech Geological Survey, Prague. ISSN 1214-1119. Manuscript received September 12, 2010; accepted in revised form October 6, 2011; published online February 10, 2012; issued February 29, 2012.

Guoxiang Li, Maoyan Zhu \& Xin Zhao, State Key Laboratory of Palaeobiology and Stratigraphy, Nanjing Institute of Geology and Palaeontology, Chinese Academy of Sciences, 39 East Beijing Road, 210008 Nanjing, China; gxli@nigpas.ac.cn,myzhu@nigpas.ac.cn, zhaoxinnanjing@yahoo.com.cn・Michael Steiner, Freie Universität Berlin, Department of Earth Sciences, Malteserstrasse 74-100, Haus D, 12249 Berlin, Germany; steiner@zedat.fu-berlin.de

The apparent abundance of sclerite-bearing metazoans is a conspicuous aspect of the early Cambrian skeletal faunas (Conway Morris \& Chen 1997), and lots of the so-called small shelly fossils represent only disarticulated sclerites, which are elements of more complex skeletons (scleritomes) (Bengtson 1985). Although the scleritomes and zoological affinities of some isolated sclerites, such as Hadimopanella-like sclerites (Hinz et al. 1990, Conway Morris 1997), Microdictyon (Chen et al. 1989), Halkieria (Conway Morris \& Peel 1990), and Paterimitra (Skovsted et al. 2009), have been well documented by discovery of extraordinarily preserved material, overall configurations of the scleritomes of many groups still remain enigmatic. In most of the above cases, previous scleritome reconstructions based on disarticulated sclerites have been shown to be inappropriate, though some analyses may provide general guidelines for studying assemblages of disarticulated sclerites or searching for more complete fossils (Bengtson \& Conway Morris 1984, Conway Morris \& Chen 1997, Dzik 2003). Discoveries of exceptionally preserved specimens have been hitherto the most convincing approach for documenting scleritomes from isolated sclerites, and the search for articulated or well phosphatized fossils continues to be an essential impetus in better understanding the biology of isolated sclerites.

The difficulties in studying early Cambrian isolated sclerite fossils could be exemplified by Mongolitubuluslike spines. The small 'phosphatic' fossil Mongolitubulus was first described by Missarzhevsky (1977) on the basis of material from the lower Cambrian of Mongolia. It is characterized by a tubular or spiniform outline with a prominent scaly ornamentation on the outer surface. This kind of spines has been widely reported from the lower Cambrian, e.g. in Mongolia (Missarzhevsky 1977), 

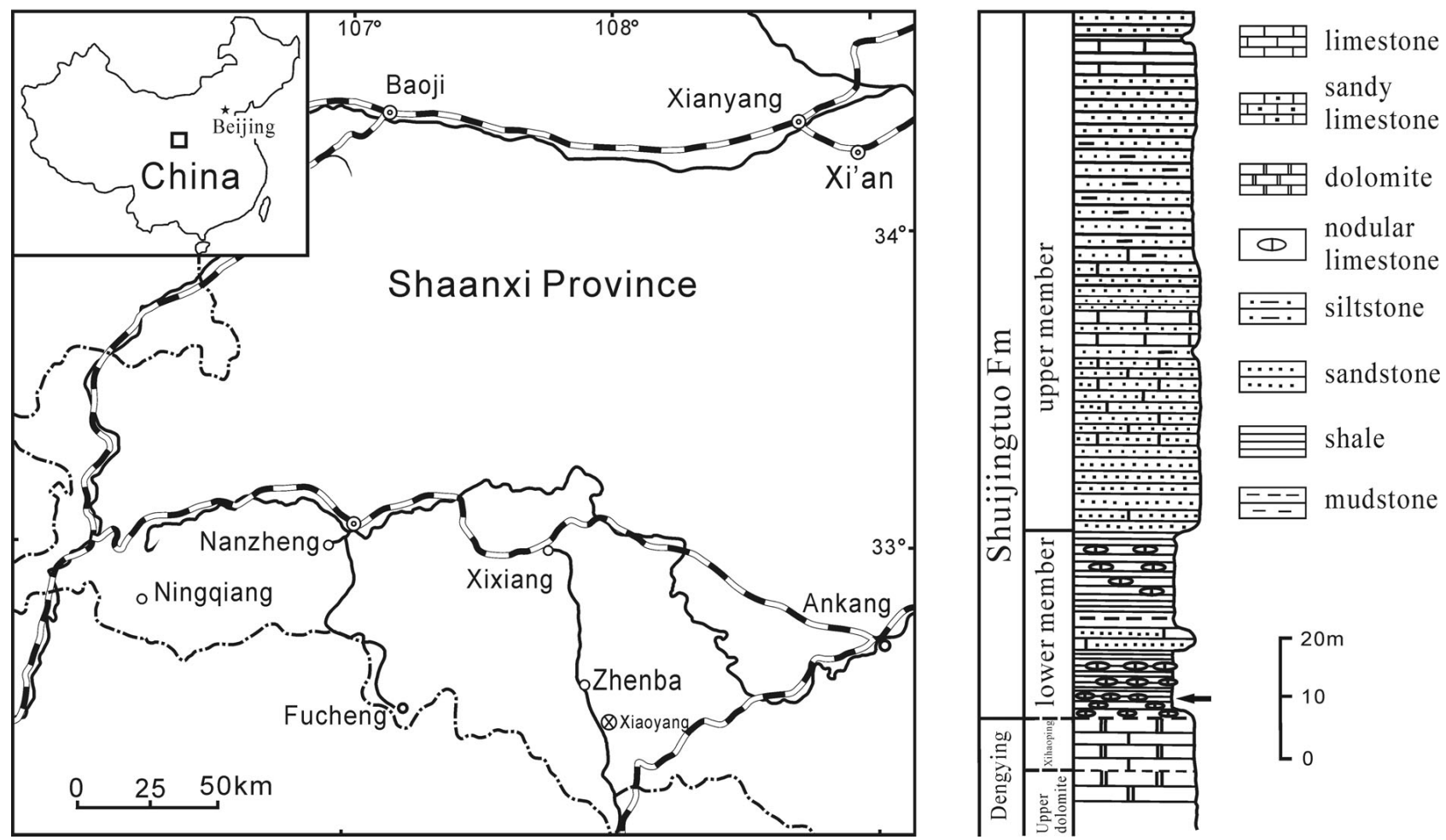

Figure 1. Geographic location and stratigraphic column of the Xiaoyang section. Level with specimens illustrated in Figs 2 to 4 is indicated by arrow.

Kazakhstan (Dzik 2003), Antarctica (Gazdzicki \& Wrona 1986), Greenland (Peel \& Blaker 1988, Skovsted \& Peel 2001), and Australia (Topper et al. 2007). Since Mongolitubulus was described mainly on the basis of isolated sclerites, its scleritome and affinities remained unresolved, being assigned to protoconodonts (Missarzhevsky 1977, Esakova \& Zhegallo 1996), or interpreted as carapace spines of bivalved arthropods (Melnikova 2000, Skovsted \& Peel 2001) or as lobopodian spines (Dzik 2003). The discovery of bradoriid specimens with scaly ornamented spines from Australia provides definitive evidence for a bradoriid affinity, at least for some Mongolitubulus-like spines (Topper et al. 2007), though it could not conclude that all scaly ornamented spines are related to bradoriids. Actually, some scaly spines somewhat resemble trilobite spines. Especially the small isopygous eodiscoid trilobites, occurring worldwide in the Lower and Middle Cambrian (Jell 1997), have an approximately coincident distribution with Mongolitubulus-like sclerites, and some of them bear genal, occipital and axial spines. Therefore, a detailed study on eodiscoid spines can possibly provide important hints for documenting the affinities of Mongolitubulus-like sclerites.

The purpose of the present paper is to document delicately phosphatized specimens of the eodiscoid Hupeidiscus orientalis from basal limestones of the Lower Cambrian Shuijingtuo Formation at the Xiaoyang section, Zhenba County, Shaanxi Province, China. The specimens were recovered from limestone samples through acetic acid (3-5\%) maceration, and were examined and photographed under SEM. The marked scaly ornamentation of the genal, occipital and axial spines of $H$. orientalis suggests that some Mongolitubulus-like sclerites can be related to eodiscoids, implying that such morphologically similar spines may have multiple pan-arthropod origins, and suggesting that Mongolitubulus shall be cautiously used as a generic name unless the circumstance of its type specimens from Mongolia can be clarified. This finding is a new paradigm of sclerites (spines) identified with body (skeleton) fossils, and indicates that some enigmatic sclerites could be related to familiar animal groups. The abundant phosphatized material also provides significant insights into the ontogenetic development of Hupeidiscus and evaluation of its relationship to other eodiscoid taxa.

\section{Locality and stratigraphy}

The specimens studied here were collected from limestones of the basal Shuijingtuo Formation at the Xiaoyang section, Zhenba County, southern Shaanxi Province (Fig. 1). The section is situated on the present-day northern margin of the Yangtze Platform. A sequence of upper Neoproterozoic to lower Cambrian stratigraphic strata well crops out along the road cut and riverbank. In an ascending order, the lower Cambrian succession consists of the Xihaoping 


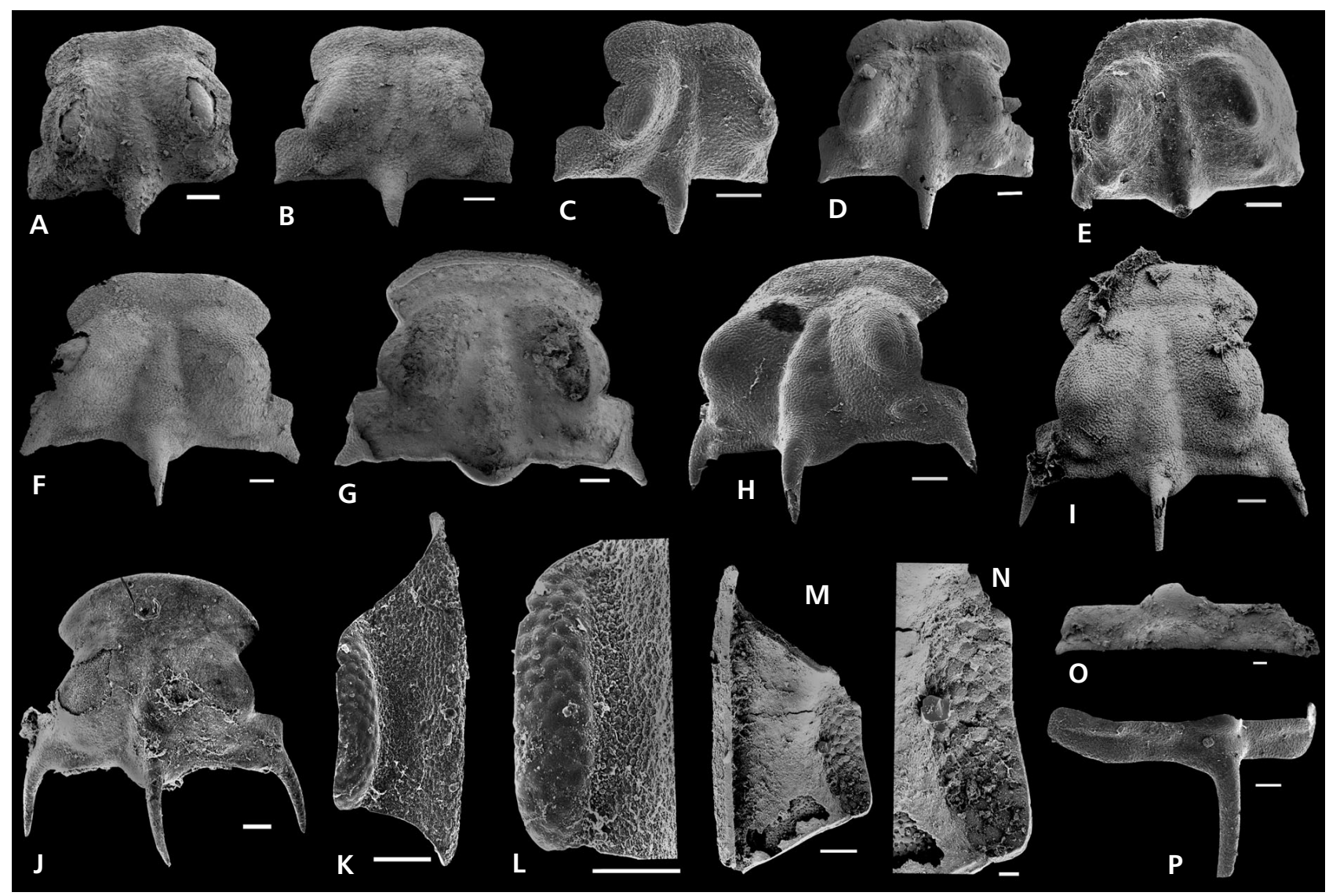

Figure 2. Hupeidiscus orientalis from the basal Shuijingtuo Formation in the Xiaoyang section. A-J showing the series changes of cranidia, K-N librigena with eyes. $\bullet$ A - NIGP153721, dorsal view of M0b. $\bullet$ B - NIGP153722, dorsal view of M0c. $\bullet$ C - NIGP153723, oblique posterodorsal view of M0c. D - NIGP153724, dorsal view of M1a. $\bullet$ E - NIGP153725, dorsal view of a cephalon of M1b. • F - NIGP153726, dorsal view of M1b. $\bullet$ G - NIGP153727, ventral view of M1b. $\bullet$ H - NIGP153728, oblique posterodorsal view of M2. $\bullet$ I NIGP153729, dorsal view of M3. $\bullet$ J - NIGP153730, dorsal view of H0. $\bullet \mathrm{K}$ - NIGP153731, dorsal view. $\bullet$ L -close-up of K. $\bullet$ M - NIGP153732, ventral view. $\bullet$ N-close-up of N. $\bullet$ O - NIGP153733, dorsal view of the first thoracic segment. $\bullet$ P - NIGP153734, dorsal view of a spine-bearing thoracic segment (second or third). Scale bars $100 \mu \mathrm{m}$, except in L $(70 \mu \mathrm{m})$ and $\mathrm{N}(20 \mu \mathrm{m})$.

Member of the Dengying Formation, and the Shuijingtuo and Shipai formations. Similar lithostratigraphic units are widely distributed in southeast Shaanxi and northwest $\mathrm{Hu}-$ bei region (Qian 1999, Steiner et al. 2007). The $8.37 \mathrm{~m}$ thick Xihaoping Member, which unconformably overlies the upper dolomite member (Ediacaran) of the Dengying Formation, consists of light dolomites and dolomitic or phosphatic limestones with abundant skeletal fossils, including phosphatic brachiopods, sponge spicules, molluscs, cambroclaviids, hyolithelminths, etc. Due to the sedimentary architecture, the Xihaoping Member was deposited in peritidal, high-energy environments (Li et al. 2004). The Shuijingtuo Formation, unconformably overlying the Xihaoping Member, can be subdivided into two members. The $31 \mathrm{~m}$ thick lower member consists of dark or black, thin-bedded siltstones, mudstones and argillaceous limestones with abundant skeletal fossils, including trilobites (eodiscoids and polymerids), lingulate brachiopods, protoconodonts and the conodont-like fossil Rhombocor- niculum cancellatum, microdictyoniid plates, sponge spicules, etc. The lower Shuijingtuo Formation is interpreted as deposited in subtidal, low-energy environments (Li et al. 2004). The $85 \mathrm{~m}$ thick upper member consists of fine sandstones and siltstones with a few intercalated thin limestone beds, and only contains scarce skeletal fossils.

Previously, the Xihaoping Member was inappropriately correlated with the Shiyantou Formation (upper Meishucunian) of eastern Yunnan (Xie 1988). Based on the occurrence of Microcornus, Cambroclavus, Ninella, etc., the Xihaoping Member has recently been considered as the middle Qiongzhusian in age (Qian 1999, Li et al. 2004, Steiner et al. 2007). Although no complete trilobite cranidia or pygidia have been collected, a great number of librigenal and occipital spines of trilobites were recovered through etching of the carbonate samples with acetic acid (Li et al. 2004). The occurrence of trilobite spines also suggests an early or middle Qiongzhusian age for the Xihaoping Member, and indicates the presence of a 
protracted hiatus at least spanning the Meishucunian between the Xihaoping and upper dolomite members. The lower Shuijingtuo Formation contains Hupeidiscus, Zhenbaspis, Eoredlichia (trilobites), and Kunmingella (a bradoriid), all of which indicate the lower Shuijingtuo Formation is of the late Qiongzhusian age (Li et al. 2004, Steiner et al. 2007). The occurrence of the cosmopolitan index fossil Rhombocorniculum cancellatum (Li et al. 2003) provides important information for global correlation of the late Qiongzhusian. The absolute time spanning the hiatus between the Xihaoping Member and the Shuijingtuo Formation is unclear. Although the upper Shuijingtuo Formation is routinely interpreted as representing the lower Canglangpuan Stage, it is difficult to draw the boundary horizon between the Qiongzhusian and Canglangpuan at the Xiaoyang section since the upper member contains only scarce fossils.

The phosphatized eodiscoid Hupeidiscus orientalis from the basal Shuijingtuo Formation co-occurs with Microdictyon spp., Rhombocorniculum cancellatum, Kunmingella douvillei, Dabashanella hemicyclica, Palaeobolus liantuoensis, and Lingulellotreta malongensis (Li \& Holmer 2004), indicating a late Qiongzhusian age (approximately equivalent to the late Atdabanian to early Botomian Siberian stages), or Stage 3 of Series 2 in the new subdivision scheme for the Cambrian System (Zhu et al. 2006).

All specimens illustrated in this paper are housed in Nanjing Institute of Geology and Palaeontology, Chinese Academy of Sciences.

\section{Ontogeny of Hupeidiscus orientalis}

\section{General features}

All specimens studied herein were collected from limestone samples of the basal Shuijingtuo Formation. The phosphatized preservation of $H$. orientalis enabled us to obtain three-dimensionally preserved specimens through acetic acid maceration in laboratory, and could add more knowledge for elucidating the ontogeny than crack-out specimens. Most of the specimens of $H$. orientalis recovered herein are disarticulated exuviae, and include hundreds of cranidia, librigenae with eyes (Fig. $2 \mathrm{~K}-\mathrm{N}$ ), (transitory) pygidia and thoracic segments of meraspids and holaspids, allowing us to describe its ontogenetic development, despite that no protaspids and hypostomes were recovered.

The moult stages and growth instars of $H$. orientalis studied herein are very similar to those of 'Shizhudiscus' longquanensis described by Zhang \& Clarkson (1993), and hence the terminology for describing the ontogeny and discriminating growth stages follows that of Zhang \& Clarkson (1993). As in 'S.' longquanensis, the ontogeny of $H$. orientalis includes three periods: protaspid (no speci- mens recovered herein), meraspid and holaspid periods. The most distinct ontogenetic changes took place in the morphogenesis of the transitory pygidia during the meraspid period, and four meraspid degrees (stages) (M0, M1, M2 and M3), defined by the progressive release of thoracic segments from the transitory pygidia, can be recognized. Seven meraspid substages or stages (M0a, M0b, M0c, M1a, M1b, M2 and M3) are subdivided according to the number of developing new rings (axial segments) in the rachis of the pygidia (Zhang \& Clarkson 1993). The holaspid period $(\mathrm{H})$ begins after the third thoracic segment being liberated from the transitory pygidium. The ontogenetic changes of the eodiscoid cranidia were fairly gradual and could not be tracked by such an evident developmental marker as was present throughout the whole growth series of the transitory pygidia (Cederström et al. 2009). Scatter diagrams of previous bivariate (length $v s$ width) analyses of eodiscoid cranidia (e.g., Zhang \& Clarkson 1993, Cederström et al. 2009) show a nearly isometric increase, and there are no distinct clusters of growth stages. Thus, bivariate analysis could not help to define growth stages of the cranidium since overlapping size ranges between adjacent instars may be generally a common feature for eodiscoids (Cederström et al. 2009). Although the cranidium and pygidium of a same individual is nearly equal in size (especially width) in isopygous eodiscoids (Zhang \& Clarkson 1993), it is difficult to refer disarticulated cranidia exactly to the corresponding growth stages of the pygidia simply on the basis of size comparison. However, a series of gradual development changes for the cranidium and discovery of complete enrolled and outstretched specimens (Zhang \& Clarkson 1993, Cederström et al. 2009) could facilitate allocation of disarticulated cranidia approximately to the growth stage defined by the transitory pygidia.

Since the ontogeny of $H$. orientalis studied herein is quite similar to that of ' $S$.' longquanensis, which was described and illustrated in detail by Zhang \& Clarkson (1993), the following paragraphs will just give a brief description of the ontogeny of $H$. orientalis with special notes on their ontogenetic differences.

\section{Meraspid period}

The majority of the disarticulated pygidia and cranidia investigated herein belong to the meraspid period. As in all trilobites, the meraspid period starts with the appearance of an articulation hinge between the cephalon and the protopygidium. Articulated trilobites lacking thoracic segment are assigned to meraspid stage 0 (M0). M0 can be subdivided into 3 substages (M0a, M0b and M0c) according to the number of axial rings in the transitory pygidium of $H$. orientalis. In substage $\mathrm{M} 0 \mathrm{a}$, the axis of the transitory 


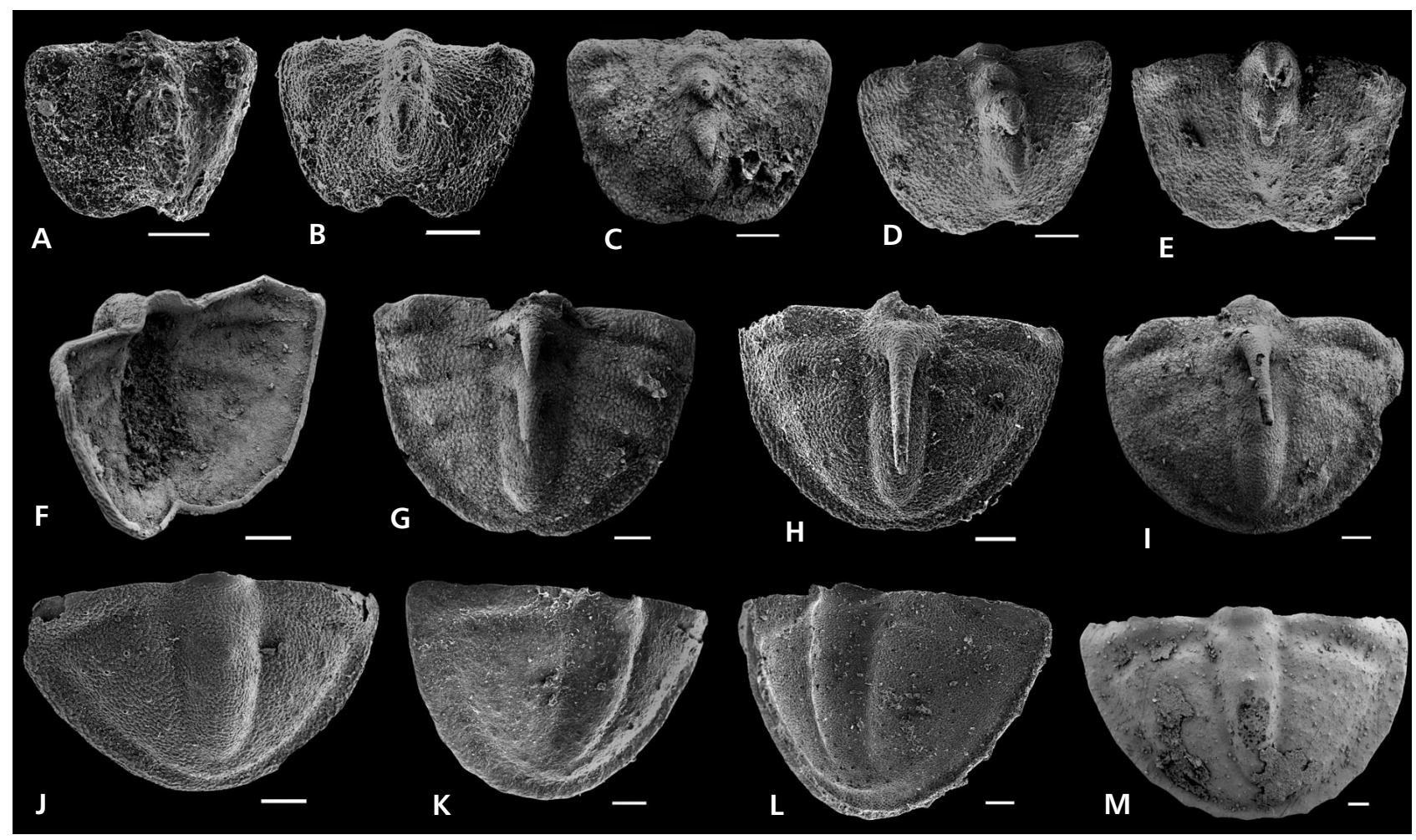

Figure 3. Pygidia of Hupeidiscus orientalis from the basal Shuijingtuo Formation in the Xiaoyang section. • A - NIGP153735, oblique posterodorsal view of M0b. • B - NIGP153736, dorsal view of M0b. • C - NIGP153737, dorsal view of M0c. • D - NIGP153738, dorsal view of M0c. - E - NIGP153739, dorsal view of M1a. • F - NIGP153740, oblique lateroventral view of M1a. • G - NIGP153741, dorsal view of M1b. $\bullet$ H - NIGP153742, dorsal view of M2. • I - NIGP153743, dorsal view of M2b or M3? • J - NIGP153744, dorsal view of H0. $\bullet$ K - NIGP153745, oblique laterodorsal view of H1. $\bullet$ L - NIGP153746, oblique lateroventral view of H1. $\bullet$ M - NIGP153747, dorsal view of H1. Scale bars $100 \mu$ m.

pygidium consists of three segments, and the two posterior axial rings bear two strong axial spines (Zhang \& Clarkson 1993). In substage MOb, an additional axial ring was added at the rear of the axis, and the transitory pygidium has four axial rings and three pleural ribs (Fig. 3A, B). In substage M0c, the pygidium bears five axial rings and four pleural ribs (Fig. 3C, D). Stage 1 (M1) has one free thoracic tergite (Fig. 2O), which was the first spineless segment released from the transitory pygidium. The transitory pygidium of M1a has five axial rings and four pleural ribs (Fig. 3E), whereas the pygidium of M1b has six axial rings and five pleural ribs (Fig. 3G). In stage M2, the first spine-bearing segment had been released from the transitory pygidium, and the trilobite has two free thoracic segments [a spineless one and one with a long axial spine (Figs 2P, 4I, K)], and the transitory pygidium of M2 bears only one axial spine and has six axial rings and five pleural ribs (Fig. $3 \mathrm{H}$ ). Before the third thoracic segment was released from the transitory pygidium, the pygidium gained a new axial ring and a pair of pleural ribs and bears seven axial rings and six pleural ribs (Fig. 3I). This stage was designated as M3 by Zhang \& Clarkson (1993, text-fig. 2), but actually it may also be considered as a substage of M2 according to the release of the thoracic segments.
Along with the size increase and moulting, the following gradual changes in morphology can be distinguished. The size of meraspid cranidia ranges from 0.40 to $1.06 \mathrm{~mm}$ in length and from 0.61 to $1.50 \mathrm{~mm}$ in width. The meraspid cranidia of stage M0 are subtrapezoidal in outline with the anterior margin curved backwards medially. During ontogenetic development, the cranidial anterior margin progressively becomes curved forwards, and the cranidia are approximately semi-circular in outline. The anterior border becomes wide and moderately convex. The fixigenal lobes are strongly convex in early meraspid stages, and become moderately convex in later ontogenetic stages. The paired bacculae posterior to the fixigenal lobes are distinctly convex in stage M0 (Fig. 2A-F), but they progressively disappear and are fused into the fixigenal lobes in holaspides (Fig. 2J). The posterior border furrows appear in late meraspid stages, and become distinct in the holaspid period (Fig. 2J). The genal and occipital spines undergo a progressive expansion during the ontogenetic development.

The transitory pygidia are $0.37-1.00 \mathrm{~mm}$ long, $0.51-1.60 \mathrm{~mm}$ wide. The transitory pygidium of stage M0 is also subtrapezoidal in outline, and has a pronounced larval notch (a w-shaped posterior margin) (Fig. 3A-F) 
(cf. Cederström et al. 2009). The larval notch becomes progressively indistinct in late meraspid stages (Fig. $3 \mathrm{H}$ ), and the w-shaped posterior margin becomes semicircular (Fig. 3I) with some microscopic serrations along the posterior margin (Fig. 4O). In the early meraspid stages (M0), the axis consisting of 3 to 5 strongly elevated axial rings, which are separated by indistinct axial furrows. The second and third axial rings bear a prominent spine with the apex pointing backwards. The lateral and posterior borders are moderately convex, and separated from the pleural areas by shallow border furrows. A few tubercles, arranged in rows, occur on each pleural rib in late meraspides (Fig. 4M, O). The tubercles are not apparent on the rachis. The pleural furrows become more indistinct during the ontogeny. The number of axial rings in the transitory pygidium increases throughout meraspid development until the third thoracic segment is liberated. The cephala and pygidia become progressively more convex during meraspid ontogeny.

\section{Early holaspid period}

The holaspid period begins after the third thoracic segment has been liberated from the transitory pygidium (Zhang \& Clarkson 1993). The pygidium of HO bears six axial rings and five pairs of pleural ribs (Fig. 3J). With further growth, the pygidium develops a new and final axial ring and a pair of pleural ribs, and the mature pygidium (H1) bears seven axial rings and six pairs of pleural ribs (Fig. 3K-M). The cranidia of the early holaspides (Fig. 2J) are very similar to those of later meraspides in morphology. As the cranidia increase progressively in size, the anterior border furrow becomes wide and deep, and the anterior border widens. The palpebral lobe becomes distinct, and the glabella becomes tapered forwards and less elevated but with the occipital ring and the posterior lobe of the glabella much swollen. The transverse glabellar furrows become visible and the axial furrows get wide and deep. The occipital and posterior furrows get deep and more evident (Fig. 2J). The occipital and genal spines progressively become elongated and more prominent.

The spineless holaspid pygidium is semicircular with a rounded posterior margin, and is moderately convex with axis raised high above the pleural areas. Both the rachis and the pleural regions are strongly fused. The ring furrows and pleural and interpleural furrows are nearly effaced. The distinct tubercles (Fig. 3K, M) arranged in rows on the pleural regions provide means for distinguishing the pleural ribs, though only the anterior pleural furrow is evident. The axial and border furrows become deep and narrow. The border slopes laterally and becomes relatively narrow with a weakly serrated margin.

\section{Thoracic segments}

The present material includes dozens of isolated thoracic segments, but most of them are fragmentary. The width variation of size indicates that these thoracic segments belong to different meraspid and holaspid stages. The holaspid thorax of $H$. orientalis consists of three segments. All segments have an arched articulating half-ring anteriorly and a larger axial ring posteriorly, which is slightly broader and longer than the articulating half-ring (Fig. 4I, K). The spineless thoracic segment represents the first of the three thoracic segments (Fig. 2O) (Zhang \& Clarkson 1990), while the second and third ones each bear a very long axial spine (Figs 2P, 4I, K) though the differentiation of these two thoracic segments is difficult because of their strong morphological similarities. The posterior segments have prominent articulating facets anterolaterally (Fig. 4K). Both the anterior and posterior edges of the thoracic segments are virtually straight with a moderately deep pleural furrow. The abaxial parts of the pleura slope downwards.

\section{Librigena and eyes}

The material has yielded dozens of isolated librigena with the eyes preserved. The size, outline and course of the facial suture indicate that these librigena belong mainly to the holaspid period. Only one cephalon (Fig. 2E), which was identified as a meraspis of substage M1b, was found with both librigena intact. It possibly represents the remains of a dead individual rather than an exuvium (Zhang \& Clarkson 1993). The eye development of 'Shizhudiscus' longquanensis has been studied by Zhang \& Clarkson (1990, 1993) in detail. They showed that a holochroal type of eye developed from a single lens through a pattern of hexagonal close packing as more lenses are emplaced. The eye development of Hupeidiscus orientalis as illustrated herein (Fig. $2 \mathrm{~K}-\mathrm{N}$ ) is essentially identical to that of 'S.' longquanensis, and will therefore not be reiterated. The cephalon of substage M1b might provide supplementary data for analyzing the eye development, but the lenses are too poorly preserved to be described.

\section{Ornamentations of exoskeletons and spines}

The phosphatization of eodiscoids in South China is related to the early Cambrian phosphate concentration episode (Zhang 1989; Zhang \& Clarkson 1990, 1993). The diagenetic phosphatization resulted in the delicate preservation of exoskeletons (including the surficial sculpture). The exoskeleton of Hupeidiscus orientalis consists of an outer layer and an inner one. The external surface of the outer 


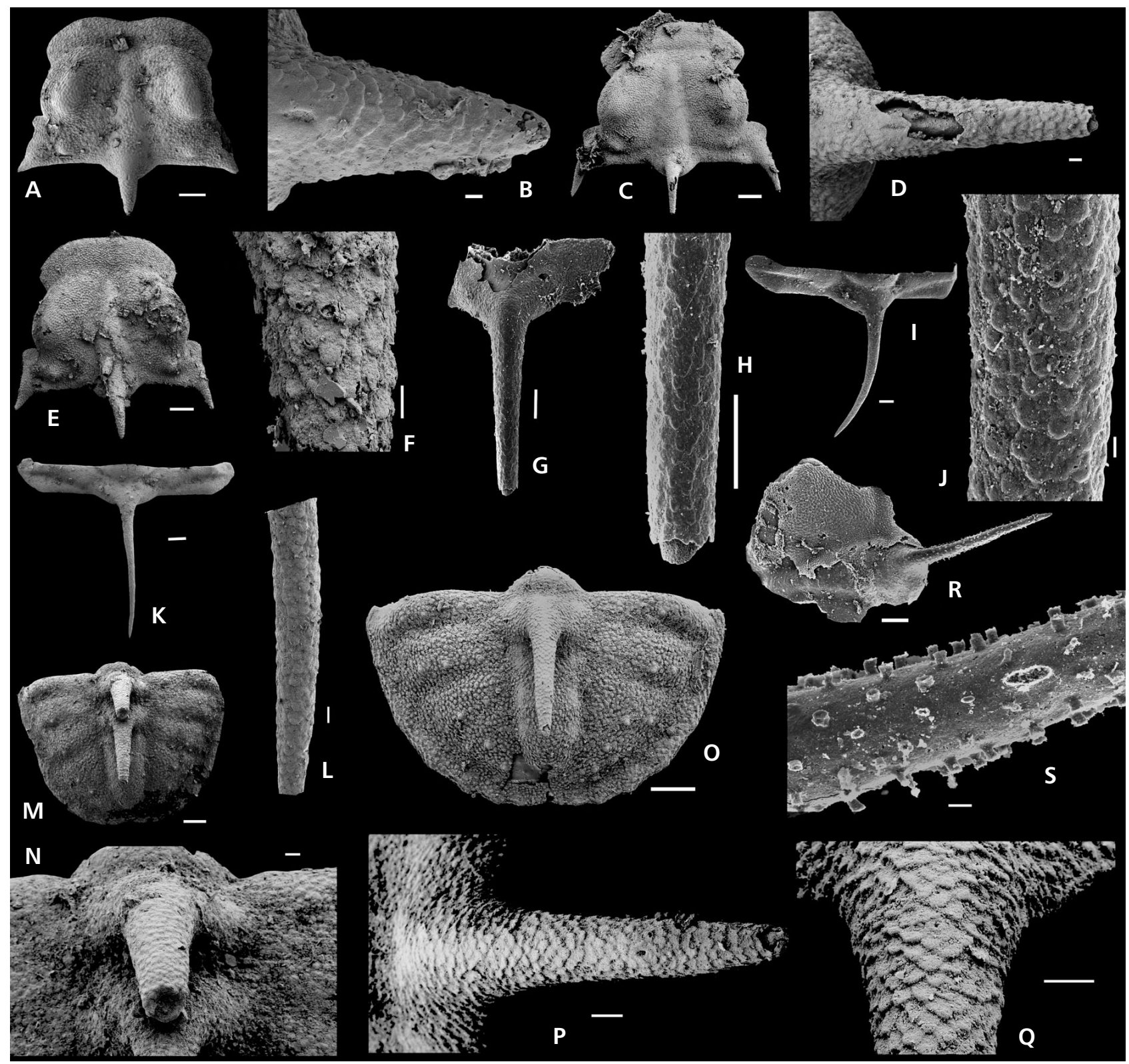

Figure 4. Hupeidiscus orientalis from the basal Shuijingtuo Formation in the Xiaoyang section, showing the ornamentation variation of the spines. - A - NIGP153748, dorsal view of a cranidium (M0c). B - close-up of the occipital spine in A; scale bar $20 \mu \mathrm{m}$. ${ }^{\mathrm{C}}$ - NIGP153749, dorsal view of a cranidium (M3). D - close-up of the occipital spine in C; scale bar $10 \mu \mathrm{m}$. $\bullet$ E - NIGP153750, dorsal view of a cranidium (M2). $\bullet$ F - close-up of the occipital spine in E; scale bar $10 \mu \mathrm{m}$. $\bullet \mathrm{G}$ - NIGP153751, an axial spine. $\bullet \mathrm{H}$ - close-up of G. $\bullet$ I - NIGP153752, a spine-bearing thoracic segment. $\bullet \mathrm{J}-$ close-up of the spine in I; scale bar $10 \mu \mathrm{m}$. $\bullet \mathrm{K}$ - NIGP153753, a spine-bearing thoracic segment. $\bullet \mathrm{L}$ - close-up of the spine in $\mathrm{K}$; scale bar $20 \mu \mathrm{m}$. $\bullet \mathrm{M}-$ NIGP153754, dorsal view of a pygidium (M1b). $\bullet \mathrm{N}$ - close-up of the spine in M; scale bar $20 \mu \mathrm{m}$. $\bullet \mathrm{O}$ - NIGP153755, dorsal view of a pygidium. $\bullet \mathrm{P}$ close-up of the spine in $\mathrm{O}$; scale bar $20 \mu \mathrm{m}$. $\bullet \mathrm{Q}$ - close-up of P; scale bar $20 \mu \mathrm{m}$. $\bullet \mathrm{R}-\mathrm{NIGP} 153756$, a fragmentary cranidium. $\bullet \mathrm{S}-$ close-up of the spine in $\mathrm{R}$; scale bar $20 \mu \mathrm{m}$. Scale bars $100 \mu \mathrm{m}$, if not otherwise indicated.

layer is ornamented with fine granules. The size of the granules (5-7 $\mu \mathrm{m}$ in diameter) does not much change during growth (M1b to H1). The outer surface of the inner layer is nearly smooth except for some tubercles (Fig. 3M). Some specimens are covered with diagenetic coatings or encrustations, and hence, the sculpture could not be examined (Figs 2A, 3H). Occasionally, some pyrite crystals can be observed on the surface (Fig. 2D, E). The granules are more or less even distributed on the cranidia except that there are relatively fewer granules in the axial furrows. Compared with the granular outer layer, the outer surface of the inner layer is more or less smooth but covered with scattered tubercles. Occasionally, some pygidia can be examined with only the outer layer preserved (Fig. 3L), and 
the internal surface of the outer layer is full of small pits (corresponding to the granules) with scattered larger pits (corresponding to the tubercles). The tubercles (15-18 $\mu \mathrm{m}$ in diameter) are most common on the pygidia. They scarcely occur on the cranidia and the thoracic segments. The tubercles first appear during substage M0b on the new developing pleural ribs. The anterior three pairs of pleural ribs usually lack tubercles.

The axial spines of late meraspid and holaspid stages are slender, slightly curved posteriorly towards the body, and taper gradually to a pointed apex. In contrast to the granular ornamentation of the major exoskeleton, the axial, occipital and genal spines are usually characterized by a prominent scale-like ornamentation on the outer surface. The ornamentation often consists of densely-spaced, ovoid to diamond-shaped scales arranged in regular rows (Fig. 4M-Q). Individual scales merge with the general surface at their abapical margin and have a raised apical end pointing towards the spine tip. Actually, the scaly ornamentation is just a transformation of the external granules on the exoskeletonal surface, and the transformation occurs at the base of the spine (Fig. 4N, P). The specimens illustrated herein exhibit a substantial variation in the morphology of the scales. In some specimens, the scales are much subdued and irregular both in morphology and arrangement (Fig. 4G-J). On the surface of the inner layer (outer layer partly peeled off) (Fig. 4R, S), the spine bears some micro-spines.

\section{Discussion}

\section{Taxonomic implications}

The eodiscoids are a group of diminutive miomerid trilobites and a common element in many Cambrian faunas (Zhang et al. 1980, Jell 1997). Its systematic position, especially its relation with agnostids, has been extensively discussed in literatures. There are two major views about the systematic feature of the eodiscoids: they are either traditionally classified together with the agnostoids, which were thought to be derived from the eodiscoids (Fortey 1990), or they are considered to have evolved from polymerid trilobites by paedomorphosis (Shergold 1991, Jell 1997). A cladistic analysis showed that the eodiscoids were derived from polymerids through progenetic heterochrony (Babcock 1994). The ontogenetic development (e.g. morphological changes, hypostomal development and the presence of calcified protaspides) provides important evidence for analyzing the systematic position of the eodiscoids, supporting the view that they are related to polymerid trilobites (Cederström et al. 2009).

Eodiscoids have been recovered in abundance from the lower Cambrian of South China, especially from the black shale or siltstone units, e.g., the Yu'anshan Formation in eastern Yunnan, the Niutitang Formation in Guizhou, the Jiulaodong Formation in western Sichuan, and the Shuijingtuo Formation in northwestern Hubei and southern Shaanxi (Lu 1974, Li 1980, Zhang et al. 1980, Zhang 1987, Zhang \& Clarkson 1993, Yuan \& Zhao 1999, Lin et al. 2004). Many genera and species have been established on the basis of material from these regions, and the taxonomic proliferation is quite obvious since the ontogenetic development and morphological variation were not sufficiently evaluated in many taxonomic studies. In reviewing these eodiscoid genera, Zhang (1987) considered Shizhudiscus Zhang \& Zhu in Zhang et al., 1980 and Guizhoudiscus Zhang in Zhang et al., 1980 to be junior synonyms of Hupeidiscus Chang in Lu et al., 1974, and Mianxiandiscus Zhang \& Zhu in Zhang et al., 1980 and Emeidiscus to be junior synonyms of Tsunyidiscus Chang, 1966. Jell (1997) further regards Shizhudiscus, Guizhoudiscus, Hupeidiscus, Mianxiandiscus, and Emeidiscus as junior synonyms of Tsunyidiscus.

Amongst these genera, Hupeidiscus and Shizhudiscus are most closely related and distinguished largely on the basis of differences in the morphology of the pygidium (with pleural furrows or not). Zhang \& Clarkson (1993) kept the synonymization open and cautiously retained Shizhudiscus as a valid generic name since the ontogeny of Hupeidiscus was poorly known. The present study shows that the ontogenetic developments of ' $S$.' longquanensis and $H$. orientalis are quite similar, especially with respect to the development of the pygidium, suggesting that Shizhudiscus is a junior synonym of Hupeidiscus. There are, however, some differences between $H$. orientalis and ' $S$ '. longquanensis. During growth, the short genal spikes of $H$. orientalis progressively increase and develop into long fixigenal spines, whereas the short genal spikes of ' $S$ '. longquanensis become reduced and the genal angles are rounded in holaspides (no fixigenal spines). In early meraspides of ' $S$ '. longquanensis, the anterior border bears two distinct tubercles anteriorly (Zhang \& Clarkson 1993), whereas the anterior border of $H$. orientalis lacks the tubercles. In contrast to the smooth holaspid pygidium of $H$. orientalis, the holaspid pygidium of ' $S$ '. longquanensis bears distinct pairs of pleural furrows. These differences show that they shall belong to two separate species.

The relationship between Hupeidiscus and Tsunyidiscus is much unclear. The cranidium of Tsunyidiscus is mainly characterized by having a row of nodes on the anterior border. The ontogeny of Tsunyidiscus is not well known for lack of three-dimensionally preserved specimens. In addition, Hupeidiscus usually occurs in younger strata than Tsunyidiscus (Steiner et al. 2001, Yang et al. 2003), and they rarely co-occur. Hence, we suggest that Hupeidiscus should be retained as a valid genus until more is known about the ontogeny of Tsunyidiscus. 
Implications for affinities of the Mongolitubulus-like sclerites

Mongolitubulus Missarzhevsky, 1977 was established on the basis of isolated tube (spine)-like fossils with prominent scale-like external ornamentation, and it was originally described as a protoconodont. As mentioned above, the affinities of these tube- or spine-like fossils have been controversial. Recently, Mongolitubulus has been tentatively considered to represent the detached spines of phosphatocopiids or bradoriids (Skovsted \& Peel 2001, Melnikova 2000) or lobopodians (Dzik 2003). The discovery of bradoriid specimens with Mongolitubulus-like spines from Australia provides definitive evidence for a bradoriid affinity for some of these spines (Topper et al. 2007).

Eodiscoid trilobites have a global distribution during early and middle Cambrian times. Phosphatized specimens show that their external skeleton surfaces are usually covered with granules. Little attention has been paid to the surface sculpture of the spines in eodiscoids since the micro-spines of crack-out specimens are usually not well preserved for examination of their ornament. The specimens obtained from acid maceration are usually threedimensionally preserved, and enable a detailed examination of the spine ornamentation. Specimens of $H$. orientalis from southern Shaanxi illustrated herein show that the spines have a distinct scale-like sculpture, which resemble that of the Mongolitubulus-like spines. Generally, eodiscoids have two kinds of spines, fixigenal spines and axial (occipital and thoracic) spines. The recognition of two kinds of Mongolitubulus spines from the Lower Cambrian of Kazakhstan (Dzik 2003) is somewhat consistent with the two kinds of eodiscoid spines (genal and axial). The palaeogeographic and stratigraphic distribution patterns of eodiscoids and Mongolitubulus are fairly similar: worldwide occurrence in the lower and middle Cambrian (Zhu et al. 2004). Mongolitubulus spines show no evidence of incremental growth but growth following moulting (Skovsted \& Peel 2001, Dzik 2003). These pieces of evidence indicate that at least some Mongolitubulus-like spines can represent spines of eodiscoids. An integration of prior studies and the present finding implies that morphologically similar sclerites may have essentially of multiple origins among the ecdysozoans (eodiscoids, bradoriids, other bivalved arthropods, lobopodians, etc.). These discoveries reveal that those spines with scale-like ornaments may actually be of morphologic analogues of convergent evolution, and the similarity may be just of functional significance with less value for taxonomy. Hence, Mongolitubulus shall be cautiously used as a generic name unless the circumstance of its type specimens from Mongolia gets clarified. Furthermore, the spines of the eodiscoids described herein preserve a wide spectrum of ornamentation patterns, indicating that the ornamentation is an unreliable feature for discriminating taxa.

\section{Conclusions}

The well preserved, phosphatized specimens of $H$. orientalis from the Shuijingtuo Formation permit us to better understand its meraspid to holaspid ontogenetic development and to study the zoological affinities of Mongolitubulus-like sclerites. The most distinct ontogenetic changes of $H$. orientalis occur in the morphogenesis of the transitory pygidia during the meraspid period. Seven meraspid substages (stages) (M0a, M0b, M0c, M1a, M1b, M2 and M3) can be distinguished on the basis of the progressive release of thoracic segments from the transitory pygidia and by the number of new developing rings (axial segments) in the pygidial rachis. The holaspid period $(\mathrm{H})$ begins when the third thoracic segment has been liberated from the transitory pygidium. Only the anterior pair of interpleural furrows is distinct in the holaspid pygidium of H. orientalis.

The ontogeny of $H$. orientalis is closely comparable to that of ' $S$ '. longquanensis in many aspects, supporting the view that Shizhudiscus can be regarded as a junior synonym of Hupeidiscus. During ontogeny, short genal spines of $H$. orientalis progressively increase in length and develop into long fixigenal spines, whereas those of ' $S$ '. longquanensis become reduced and holaspides have rounded genal angles. The holaspid pygidium of $H$. orientalis is almost smooth except for the anterior pair of pleural furrows, whereas the holaspid pygidium of ' $S$ '. longquanensis bears distinct pairs of pleural furrows. These differences show that $H$. orientalis and ' $S$ '. longquanensis belong to two separate species. Since the ontogeny of Tsunyidiscus is not well known, and Hupeidiscus usually occurs in younger strata than Tsunyidiscus (Steiner et al. 2001, Yang et al. 2003), synonymization of Hupeidiscus with Tsunyidiscus shall be cautious.

The spines of $H$. orientalis are ornamented with a distinct scale-like sculpture, which just resemble the sculpture of Mongolitubulus-like sclerites. The recognition of two kinds of Mongolitubulus spines from the Lower Cambrian of Kazakhstan is consistent with two kinds of spines of eodiscoids (genal and axial spines). The temporal and spatial distribution of both eodiscoids and Mongolitubulus are quite similar. Mongolitubulus shows no evidence of incremental growth but growth following moulting. These pieces of evidence indicate that Mongolitubulus-like spines may be essentially of multiple pan-arthropod origins (bradoriids, eodiscoids, etc.), and they may be of morphologic analogues rather than homologues, suggesting that Mongolitubulus should be cautiously used as a generic name until the circumstance of its type specimens is clarified. This study shows that some problematic sclerites of many early Cambrian small shelly fossils with a bizarre appearance may have affinities with familiar animal groups. 


\section{Acknowledgments}

This work was financially supported by the Chinese Academy of Sciences (KZCX2-EW-115), the National Natural Science Foundation of China, and the German Natural Science Foundation (DFG). We thank J. Zhang and A. Yang for assistance in the fieldwork and discussions, Y. Mao for SEM microphotography, and Y. Meng for acid maceration and picking fossils. Critical reviews and constructive comments by P. Ahlberg and O. Elicki significantly improved the manuscript.

\section{References}

BАВСоCK, L.E. 1994. Systematics and phylogenetics of polymeroid trilobites from the Henson Gletscher and Kap Stanton formations (Middle Cambrian), North Greenland. Bulletin Grønlands Geologiske Undersøgelse 169, 79-127.

Bengtson, S. 1985. Taxonomy of disarticulated fossils. Journal of Paleontology 59, 1350-1358.

Bengtson, S. \& Conway Morris, S. 1984. A comparative study of Lower Cambrian Halkieria and Middle Cambrian Wiwaxia. Lethaia 17, 307-329.

DOI 10.1111/j.1502-3931.1984.tb00677.x

Cederström, P., Ahlberg, P., Clarkson, E.N.K., Nilsson, C.H. \& AxheImer, N. 2009. The Lower Cambrian eodiscoid trilobite Calodiscus lobatus from Sweden: morphology, ontogeny and distribution. Palaeontology 52, 491-539.

DOI 10.1111/j.1475-4983.2009.00858.x

Chang, W.T. 1966. On the classification of Redlichiacea, with description of new families and new genera. Acta Palaeontologica Sinica 14, 135-184. [in Chinese with English summary]

Chen, J.Y., Hou, X.G. \& Lu, H.Z. 1989. Early Cambrian netted scale-bearing worm-like sea animal. Acta Palaeontologica Sinica 28, 1-16. [in Chinese with English summary]

Conway Morris, S. 1997. The cuticular structure of the 495-Myr-old type species of the fossil worm Palaeoscolex, $P$. piscatorum (?Priapulida). Zoological Journal of the Linnean Society 119, 69-82.

DOI 10.1111/j.1096-3642.1997.tb00136.x

Conway Morris, S. \& Chen, M. 1997. Cambroclaves and paracarinachitids, early skeletal problematic metazoans from the Lower Cambrian of South China. Palaeontology 34, 357-397.

Conway Morris, S. \& Peel, J. 1990. Articulated halkieriids from the Lower Cambrian of North Greenland. Nature 345, 802-805. DOI $10.1038 / 345802 \mathrm{a} 0$

DzIK, J. 2003. Early Cambrian lobopodian sclerites and associated fossils from Kazakhstan. Palaeontology 46, 93-112. DOI 10.1111/1475-4983.00289

EsaKova, V.V. \& Zhegallo, E.A. 1996. Biostratigrafiya i fauna Nizhnego Kembriya Mongolii [Biostratigraphy and fauna of the Lower Cambrian of Mongolia]. 216 pp. Nauka, Moscow. [in Russian]

ForTEY, R.A. 1990. Ontogeny, hypostome attachment and trilobite classification. Palaeontology 33, 529-576.
GaZdZicki, A. \& Wrona, R. 1986. Polish paleontological investigation in West Antarctica in 1986. Prezglad Geologicyny 34, 609-617. [in Polish with English and Russian summaries]

Hinz, I., Kraft, P., Mergl, M. \& Müller, K. 1990. The problematic Hadimopanella, Kaimenella, Milaculum and Utahphospha identified as sclerites of Palaeoscolecida. Lethaia 23, 217-221. DOI 10.1111/j.1502-3931.1990.tb01362.x

JELL, P.A. 1997. Introduction to Suborder Eodiscina Kobayashi 1939, 383-404. In KAESLER, R.L. (ed.) Treatise on invertebrate paleontology. Part O. Arthropoda 1. Trilobita, Revised. Volume 1, Introduction, Order Agnostida, Order Redlichiida. Geological Society of America and University of Kansas, Boulder, Colorado and Lawrence, Kansas.

LI, G.X. \& Holmer, L.E. 2004. Early Cambrian lingulate brachiopods from the Shaanxi Province, China. GFF 126, 193-211. DOI 10.1080/11035890401262193

Li, G.X., Zhu, M.Y. \& Steiner, M. 2003. Microstructure and functional morphology of the Early Cambrian problematical fossil Rhombocorniculum. Progress in Natural Science 13, 831-835. DOI 10.1080/10020070312331344510

Li, G.X., Zhu, M.Y., Steiner, M. \& Qian, Y. 2004. Skeletal faunas from the Lower Cambrian Qiongzhusian of southern Shaanxi: biodiversity and lithofacies-biofacies links in carbonate settings. Progress in Natural Science 14, 91-96. DOI 10.1080/10020070412331343201

LI, S.J. 1980. Trilobites from the Chiulaotung Formation (Lower Cambrian) in Mt. Emei area, western Sichuan. Acta Palaeontologica Sinica 19, 42-50. [in Chinese with English summary]

Lin, T.R., Peng, S.C. \& Zhu, X.J. 2004. Restudy on the eodiscoids from the Shuijingtuo Formation (Early Cambrian) in eastern Yangtze Gorge area, western Hubei. Acta Palaeontologica Sinica 43, 502-514. [in Chinese with English summary]

Lu, Y.H., Chang, W.T., Qian, Y.Y., Zhu, Z.L. \& Lin, H.L. 1974. Cambrian trilobites, 82-107. In NANJING InstituTE OF GeOlogy And PALAEONTOLOGy (ed.) Handbook of stratigraphy and palaeontology in southwestern China. $454 \mathrm{pp}$. Science Press, Beijing. [in Chinese]

Melnikova, L.M. 2000. A new genus of Bradoriidae (Crustacea) from the Cambrian of northern Eurasia. Paleontological Journal 34, 180-185.

Missarzhevsky, V.V. 1977. Konodonty (?) i fosfantnye problematiki kembriya Mongolii i Sibiri [Conodonts (?) and phosphatic problematica from the Cambrian of Mongolia and Siberia], 10-19. In TATARINOv, L.P. (ed.) Bespozvonochnye Paleozoya Mongolii. Trudy Sovmestaya Sovetsko-Mongolskaya Paleonotologicheskaya Ekspeditsiya. Nauka, Moscow. [in Russian]

Peel, J.S. \& Blaker, M.R. 1988. The small shelly fossil Mongolitubulus from the Lower Cambrian of North Greenland. Rapport Grønlands geologiske Undersøgelse 137, 55-60.

QIAN, Y. 1999. Taxonomy and biostratigraphy of small shelly fossils in China. 247 pp. Science Press, Beijing. [in Chinese with English summary]

SHERGOLD, J.H. 1991. Protaspid and early meraspid growth stages of the eodiscoid trilobite Pagetia ocellata Jell. Alcheringa 15, 65-86. DOI 10.1080/03115519108619010 
Skovsted, C.B. \& Peel, J.S. 2001. The problematic fossil Mongolitubulus from the Lower Cambrian of Greenland. Bulletin of the Geological Society of Denmark 48, 135-147.

Skovsted, C.B., Holmer, L.E., Larsson, C.M., Högström, A.E.S., Brock, G.A., Topper, T.P., Balthasar, U., Stolk, S.P. \& PAterson, J.R. 2009. The scleritome of Paterimitra, an Early Cambrian stem group brachiopod from South Australia. Proceeding of the Royal Society of London B 276, 1651-1656. DOI 10.1098/rspb.2008.1655

Steiner, M., Li, G.X., Qian, Y., Zhu, M.Y. \& Erdtmann, B.-D. 2007. Neoproterozoic to early Cambrian small shelly fossil assemblages and a revised biostratigraphic correlation of the Yangtze Platform (China). Palaeogeography, Palaeoclimatology, Palaeoecology 254, 67-99. DOI 10.1016/j.palaeo.2007.03.046

Steiner, M., Zhu, M.Y., Weber, B. \& Geyer, G. 2001. The Lower Cambrian of eastern Yunnan, trilobite-based biostratigraphy and related faunas. Acta Palaeontologica Sinica 40 (Supplement), 63-79.

Topper, T.P., Skovsted, C.B., Brock, G.A. \& Paterson, J.R. 2007. New bradoriids from the lower Cambrian Mernmerna Formation, South Australia, systematics, biostratigraphy and biogeography. Memoirs of the Association of Australasian Palaeontologists 33, 67-100.

XIE, Y.S. 1988. Small shelly fossils in Qiongzhusi Stage of Lower Cambrian in Zhenba County, Shaanxi Province. Journal of Chengdu College of Geology 15(4), 21-29. [in Chinese with English summary]

Yang, A.H., Zhu, M.Y., Zhang, J.M. \& Li, G.X. 2003. Early Cambrian eodiscoid trilobites of the Yangtze Platform and their stratigraphic implications. Progress in Natural Science 13, 861-866. [in Chinese with English summary] DOI 10.1080/10020070312331344560
YuAn, J.L. \& ZhaO, Y.L. 1999. Subdivision and correlation of Lower Cambrian in southwest China, with a discussion of the age of Early Cambrian Series biotas. Acta Palaeontologica Sinica 38 (Supplement), 116-131. [in Chinese with English summary]

ZhANG, W.T. 1987. World's oldest Cambrian trilobites from Yunnan, 1-17. In Nanjing Institute of Geology and Palaeontology, Academia Sinica (ed.) Stratigraphy and Palaeontology of Systemic boundaries in China, Precambrian-Cambrian boundary 1. Nanjing University Publishing House, Nanjing.

Zhang, W.T., Lu, Y.H., Zhu, Z.L., Qian, Y.Y., Lin, H.L., Zhou, Z.Y., Zhang, S.G. \& Yuan, J.L. 1980. Cambrian trilobite faunas of southwestern China. Palaeontologica Sinica, New series B 16,1-497. [in Chinese with English summary]

Zhang, X.G. 1989. Ontogeny of an Early Cambrian eodiscoid trilobite from Henan, China. Lethaia 22, 13-29. DOI 10.1111/j.1502-3931.1989.tb01164.x

Zhang, X.G. \& Clarkson, E.N.K. 1990. The eyes of Lower Cambrian eodiscid trilobites. Palaeontology 33, 911-932.

Zhang, X.G. \& Clarkson, E.N.K. 1993. Ontogeny of the eodiscid trilobite Shizhudiscus longquanensis from the Lower Cambrian of China. Palaeontology 36, 785-806.

Zhu, C.F., LI, G.X. \& Dong, X.P. 2004. Ornamented tubules from Middle Cambrian of Huayuan, west Hunan, China. Acta Scientiarum Naturalium Universitatis Pekinensis 40, 193-202. [in Chinese with English summary]

Zhu, M.Y., Babcock, L.E. \& Peng, S.C. 2006. Advances in Cambrian stratigraphy and paleontology, integrating correlation techniques, paleobiology, taphonomy and paleoenvironmental reconstruction. Palaeoworld 15, 217-222. DOI j.palwor.2006.10.016 